\title{
Women as The Victim of Stereotypes in Sintren
}

\author{
Hiqma Nur Agustina ${ }^{1}$ \\ ${ }^{1}$ English Department, State Polytechnic of Malang
}

\begin{abstract}
The role of women in dance in Indonesia can raise the local wisdom of an area such as a rural one. One of the pretty phenomenal arts is Sintren. The peculiarity of Sintren originating from the area in Pemalang appoint as a novel entitled Sintren by Dianing Widya Yudhistira. This paper aims to show that stereotypes of women are very influential in repressing their thoughts and actions so that they live in shackles and cannot determine the path of life they choose. Women from low backgrounds often stereotype being ugly, poor, unkempt, so they want to become a Sintren dancer who is very close to magical elements but can transform into beautiful women and have lots of money. This stereotype negates the existence of women who should be free from the shackles of the ideal woman stereotype: beautiful, rich, and adored by many men. This study uses a qualitative descriptive method using library data. The concepts of gender relations, patriarchal culture, and a feminist approach use as analysis tools. The author raises the story of Sintren in a literary work to show women who are often victims of stereotypes that colonize their bodies and minds. As a result, this novel reinforces the weak position of rural women and often becomes the victim of stereotypes and stigma that exist in society.
\end{abstract}

\section{Introduction}

Poverty is one of the causes of women becoming victims of subordination, stereotypes, marginalization, and stigma. Inability in the economy is the main trigger for rural women to become victims of various things that repress their souls and lives. They try various ways to get out of various kinds of shackles of repression, such as becoming migrant workers abroad, becoming local workers in their own country, and other fields such as culture, namely as dancers. Many literary works use as a social criticism of problems that exist in real life [1].

Literary works can see as socio-cultural documents. It bases on the view that literary works record the socio-cultural reality at a specific time [2]. All events that become the background are a reflection of the social conditions of the people behind

*Corresponding author: hiqma@polinema.ac.id 
them. Therefore, the society that emerges is a factual existence. Literary works that reflect the conditions of poverty and women see in the novel Sintren. Sintren is a traditional dance art of the people of Central Java in the northern coastal region, especially in Pemalang. This art is famous on the north coast of Central Java and West Java, such as Pemalang, Pekalongan, Brebes, Banyumas, Kuningan, Cirebon, Inramayu, and Jatibarang. Sintren is known as a traditional dance that contains magical elements [3]. This dance comes from the story of Sulasih and Sulandono. The name Sintren in this dance turns out to be a combination of two rich, namely si and tren, which in Javanese the word si is an expression of calling which means her, while the word trend comes from the word tri or princess, so Sintren means the princess or the dancer. Sintren plays by a girl who is still holy, assisted by the handler accompanied by the accompaniment of 6 people. First, the girl puts in a chicken cage covered with a cloth. The handler or puppeteer then walks around the chicken cage while chanting a spell to summon the spirit of Dewi Lanjar. If the summoning of Dewi Lanjar's spirit is successful, then when the cage opens, the girl is free from the bonds and is dressed beautifully, then dances to the accompaniment of gending.

A study conducted by Darmoko said that the art of Sintren had been eroded by modernity so that it is now rarely found. In addition, the results of the study also stated that three groups gave different responses about the existence of Sintren art. First, community groups firmly and uncompromisingly reject the existence of Sintren art because they assume that Sintren art is not in line with religious reasoning, which is full of mystical nuances. Second, a group that recognizes the existence of Sintren art and tries to preserve it. Artists and observers of ethnic art represent this group. Third, the group that does not care about Sintren and the future of this art. Research on Sintren from studies on women and gender relations has not been found significantly [4].

\section{Stereotypes in Sintren}

Sintren is a novel that relates with stories about Javanese women, is in line with the research conducted by Kuntjara [5]. The description of women in Javanese shows that women are more often used as objects to watch and paint. For this reason, there are also reasons why many paintings in the museum prefer female objects to male objects. There are more male painters than female painters. Therefore, women are more suitable as objects of painting.

Gender is not always related to physiological differences, as has been found in society. Gender divides attributes and occupations into masculine and feminine. Usually, masculine is occupied by the male gender, while feminine by the female gender. This concept then gave birth to stereotypes of women and men, which had consequences for women's subordination [6]. One form of subordination to women in Indonesia is the family system which attaches great importance to the father's lineage. Patriarchy puts women under men or treats them as inferior men.

This novel describes the story of a woman, Saraswati. The female dancer in this novel described an intelligent student from a low-income family. Her mother complies with her to marry a wealthy's son, Kirman, at her 13 ages. Then, she decided to be a traditional dancer, Sintren, to earn money for her parents. The author clearly describes some stereotypes that are identical to poor women. For example, the 
following quote explains the reluctance of Menur, the wife of Wargo, to have Saraswati's future daughter-in-law from a low-income family.

"Bapak sudah yakin dengan pilihan Bapak untuk Kirman."

"Saraswati, maksudmu?"

Menur meangangguk.

"Kulihat anaknya baik."

“Apa Bapak lupa kalau dia ...” Menur tidak meneruskan kalimatnya.

"Kamu keberatan karena dia dari keluarga miskin."

Menur hanya diam.

"Itu berarti ya, karena kau diam."

Menur menghela napas. Akhirnya bisa juga ia mengeluarkan kegelisahannya [7]

"Are you sure about your choice for Kirman."

"Saraswati, you mean?"

Menur nodded.

"I see she is a good girl."

"Did you forget that she ..." Menur did not continue her sentence.

"You mind because she is from a poor family."

Menur was silent.

"That means yes because you were quiet."

Menur sighed. Finally, she can also release her anxiety [7]

The quote above clearly shows that different social strata, rich and poor, are the main assessment elements to make Saraswati a potential wife for her child. The stereotype of poor women who are often identified with stupid, not beautiful, not competent, and cannot go to school because of lack of money is the main reason Saraswati becomes a Sintren. She negates various side effects and a magical side that can endanger her life in order to be able to attend junior high school. The poverty factor causes many rural women to have to pawn their lives and self-esteem.

Di dalam kamar, Saras sama sekali tidak dapat tidur. Pikirannya tertuju pada pertunjukan sintren nanti malam. Ia pun mulai merutuk-rutuk sendiri, mengapa mesti lahir dari Rahim perempuan miskin. Kenapa Tuhan tidak memberinya orangtua yang kaya, agar ia tidak perlu menjadi sintren untuk biaya sekolah ke SMP nanti [7].

In the room, Saras could not sleep at all. Her mind was on the Sintren show tonight. She also began to curse herself. Why should she be born from the womb of a poor woman? Why didn't God give her wealthy parents so that she would not have to become a Sintren to pay for school fees to junior high school later [7].

Gender stereotypes are expected in two or more relationships and use as an excuse to justify the actions of one group over another. Gender stereotypes also show the existence of unequal power relations that aim to conquer or dominate others. In Sintren's novel, this stereotype is carried out not only by the rich Juragan Wargo character towards Saraswati and her poor mother but also the stereotype of this poor woman has been embedded in the mind.

As a creature that is stereotyped as weak, Saraswati turns into a strong woman in a bargaining position when many men intend to marry her. However, the fact that this power exists does not play a role in bringing her happiness. Money and popularity as 
a Sintren dancer cannot give her genuine happiness to choose a man who loves and loves her, Nur, because a magical contract with a demon binds her in the form of small children who have always been an obstacle for her.

Various kinds of stereotypes that often addressed poor women make their condition worse. Not only from stereotypes related to physicality but also to economic conditions that tend to make them a group of easily humiliated, demeaned, and exiled people. The stereotype of poor people who cannot continue their education because school is not accessible for Saraswati. Being born as an intelligent and diligent girl made her have to think hard to continue school. The only way to solve the problem is to become a Sintren dancer. The stereotypes attached to Sintren dancers are also the main attraction for teenage girls in their teens in Indramayu and surrounding areas. Having much money, being famous, being an idol of men, being beautiful, and having an ideal body are things that the dancer has. For poor women, the various attributes and things they get when they become a Sintren dancer are synonymous with money, and popularity is undoubtedly a hypnotizing magnet. Without thinking, they will accept the invitation to become dancers. Unaware of the dangerous risks that come with being a dancer, they never thought about it. They only think about how to get out of poverty, earn much money, and be famous. The rest, they will regret in the end so entangled in a pact with the devil that ultimately took their lives.

\section{Women as the Victim of Gender Inequality}

Women are only one of the objects of structural oppression. The solution to this problem is not only on gender equality because it is closely related to something broader, namely the liberation of the marginalized, the economically poor, and the emancipation of the politically oppressed. Empowerment and equality must direct to crucial issues like these. In this direction, the women's movement must solve the whole series of domination problems with men. Forms of gender inequality include subordination, gender stereotypes, double burden, marginalization, and violence. All of this causes women's condition to worsen, and it is not easy to get equality with men. Gender inequality is the difference in roles and rights of women and men in social life, government, and various other sectors.

Many societies place women's social status lower than men's. Therefore, women are often victims of gender injustice [8]. Women also have to fight harder to be accepted and heard by others by trying to get the social status quo with the social construction of society about the ideal woman concept. That is why many trigger the occurrence of gender inequality against women themselves. For example, the character Sarawati born into a low-income family struggled to stay in school because she was a smart girl, but unfortunately, she did not get that opportunity, as shown in the following quote.

Coba kalau ia anak laki-laki dan anak juragan Wargo adalah anak perempuan. Mak tidak akan begitu saja pergi melamarkan anaknya ke juragan Wargo. Mak akan memikirkan berkali-kali terlebih dulu, pantaskan seorang lakilaki dengan pendidikan rendah melamar anak perempuan seorang kaya raya. Pasti Mak akan memberinya kesempatan Sekolah lebih tinggi.

Kenyataannya ia perempuan. Harus menuruti kehendak orang tua. Sekolah sangat dibatasi. Yang mengenaskan, orang-orang di kampungnya akan merasa 
senang bila anak gadisnya cepat dilamar orang, yang berarti anaknya cepat laku. Banyak teman perempuan Saraswati sudah akan dinikahkan begitu selesai Sekolah dasar nanti [7].

I think if I am a boy and Wargo's owner's son is a girl. Mak will not just go to propose her son to juragan Wargo. Mak will think many times first, is it appropriate for a man with low education to propose to the daughter of a rich man. Surely Mak will give him a chance to go to higher school.

I am a girl. Must obey the will of parents. Schools are minimal. The sad thing is that people in the village will feel happy if their daughter quickly proposes it to someone, which means that her son sells quickly. Many of Saraswati's girls' friends will already be married off after elementary school ends [9].

Fighting for gender injustice refers to efforts to fight for the position and condition of women, not the same as the struggle of women against men. However, because women's oppression does not come from men, the problem of the system and structure of social injustice is gender inequality. Women as victims of gender injustice also reflected when the figure of Saraswati, who is smart and has high enthusiasm to attend junior high school, is forced to give herself up to become a Sintren dancer. Sintren dancers who are closely related to magical elements can stay awake, healthy, intelligent, beautiful, and have a proportional body, becoming an idol woman for every man who adores her. Again, there is sexual exploitation shown in the Sintren dance performance. Everything related to the beauty of the female body present in the figure of the dancer. Again, women exploited to the full for money.

In literary works, the author certainly raises human and humanitarian problems [9]. Human and humanitarian problems arise because of the depravity or imbalance that occurs in people's lives. Moreover, this represents in the novel Sintren. The patriarchal society still has the notion that women are weak, surrender, and become sexual objects, so that in this context, the term is gender-based violence. Saraswati, at a young age, has chosen to become a Sintren dancer in order to be able to pay for school. In her teens, she experienced gender-based violence when she appeared as a dancer on stage. The gaze of many men who are full of lust for beauty and perfect bodies is a form of sexual exploitation that endangers her. Therefore, nowadays, the tradition of Sintren dancers is no longer practiced and tends to disappear due to the growing public awareness not to make women the object of men's gaze, but must become subjects who do not demean women's position in society.

The placement of a female Sintren dancer on the stage that gives rise to lustful gazes is sexual exploitation -women as objects placed in a lower position than men. Sintren dancers identify as female entertainers for male audiences. The phenomenon of exploitation caused the power relations that play a role. This power relation causes the dancer to get money after becoming entertainment for the male audience. They are in control of the dancer. The main thing is the tradition of giving money, or Saweran collected when dancers act on stage. It can happen because of cultural and legal factors that also influence gender inequality in women. 


\section{Conclusion}

Sintren represents women who are weak, oppressed, and victims of stereotypes and gender inequality. Being born into a woman from a low-income family is not expected by everyone. Various stereotypes, stigma, and gender inequality have caused them to become victims of magical cultural practices that endanger their safety and lives. Patriarchal culture is also often the cause of various kinds of shackles that make women slump and unable to determine life direction. This novel criticizes gender inequality, which is rooted in beliefs and becomes the ideology of women and men. The female author shows the helplessness of a young girl who shackles in a patriarchal culture and lives in poverty because every woman has the same opportunities in school as men. This novel is very rich in traditional values that the author wants to preserve again. The characterization of female figures who are the main character and the entanglement of negative stereotypes and gender inequality that make women victims not only by patriarchal culture but also by negative labeling addressed to a Sintren dancer is a fact that is quite surprising.

\section{References}

1. B. Afiansah, Sumartini \& M. Intan. Peran Tokoh Perempuan dalam Mengatasi Kemiskinan pada Novel Genduk Karya Sundari Mardjuki. (Jurnal Sastra Indonesia JSI 7 (2), 2018)

2. Siswanto. Pengantar Teori Sastra. Jakarta: Grasindo. (2008)

3. B. Herusatoto. Banyumas: Sejarah, Budaya, Bahasa dan Watak. (Yogyakarta: LKiS Pelangi Aksara, 2008)

4. P. D. Darmoko. Kesenian Sintren dalam Tarikan Tradisi dan Modernitas. (Madaniyah Vol 4, No 1, 2014)

5. F. Mansour. Analisis Gender \& Transformasi Sosial. (Yogyakarta, Pustaka Pelajar, 2013)

6. E. Kuntjara. Gender, Bahasa, \& Kekuasaan. (Jakarta: PT BPK Gunung Mulia, 2012).

7. D. W. Yudhistira. Sintren. (Jakarta: PT. Grasindo, 2007)

8. E. Pertiwi. Kritik Sastra Feminis Dalam Kumpulan Cerpen Saia Karya Djenar Maesa Ayu (Feminist Literary Criticism on The Collection of Short Stories Saia by Djenar Maesa Ayu (Jurnal Bahasa, Sastra, dan Pembelajarannya 6 (1), 2016)

9. I. K. Melati. Kritik Sosial Dalam Novel Orang-Orang Biasa Karya Andrea Hirata.

10. S. Waluyo. Kritik Sosial Terhadap Sistem Hukum Dalam Novel Bukan Karena Kau Karya Toha Mohtar. Sebuah Tinjauan Sosiologis. (Jurnal Humanika, 2014). 